\title{
AINDA AS DIRETRIZES E BASES DA EDUCAÇÃO NACIONAL
}

(Reparos ao "projeto conciliador")

\section{A. Almeida Júnior}

Professor Catedrático da Faculdade de Direito da Universidade de São Paulo

O primeiro projeto de diretrizes e bases da educação nacional, elaborado em 1947 por iniciativa do Ministro Clemente Mariani, foi enviado em 1948 ao Parlamento. Teve má acolhida na Comissão de Leis Complementares (relator, sr. Gustavo Capanema); extraviou-se, reconstituiu-se, foi reapresentado. Em 1957, o Ministro Clóvis Salgado atualizou-o e, em 1959, um grupo de educadores lhe deu versão mais sintética. A despeito de tais vissitudes, o documento se conservou idêntico a si mesmo: não mudou de estrutura, manteve a fisionomia original e permaneceu sempre fiel aos princípios que o inspiraram. Por isso, ao referir-me a êle em qualquer das três versões, dar-lhe-ei um nome único, que indiscutìvelmente lhe vai bem - o de "projeto liberal".

Ao projeto liberal (e antes mesmo de ser levada à Câmara a contribuição do grupo de educadores), veio opor-se, em começos de 1959, um substitutivo inteiramente diverso. Assinava-o Carlos Lacerda, ilustre deputado cuja ideologia em matéria de educação, ajudada pelo brilho de sua palavra, atraiu em favor da nova fórmula adesões poderosíssimas, dentro e fora do Parlamento. Do choque entre as duas concepções resultou um "impasse", e, para que êste "impasse" se removesse, foi redigido novo texto, ao qual, tendo em vista a intenção dos seus autores, chamarei "projeto conciliador". Vou, através desta exposição, examinar o projeto conciliador; não, por 
certo, em todos os pormenores (o que nos levaria muito longe), mas nos aspectos de maior interêsse para a educação nacional.

Antes de começar, rendo minha homenagem aos ilustres autores do substitutivo conciliador. Merecem louvor pela diligência com que se empenharam na difícil tarefa de harmonizar os dois antagonismos e de acomodar a solução final dentro dos quadros da Constituição de 1946. Se o conseguiram, ou não, é o que procurarei averiguar. Assinalo, por fim, nesta parte introdutória - como satisfação ao narcisismo dos autores do projeto liberal (entre os quais me acho) - que os que elaboraram o substitutivo de agora não só conservaram a estrutura geral do primitivo trabalho e lhe reproduziram a distribuição da matéria, como também adotaram freqüentemente a sua redação. E, o que mais importa, endossaram na maioria dos casos as soluções didáticas consignadas naquela proposta. Houve inovações: não muitas; vantajosas algumas; outras, a meu ver, prejudiciais; acresceram-se superfluidades e praticaram-se omissões, umas e outras, por vêzes, de grande significação doutrinária. E deu-se expressão concreta a receios que pairavam no ar desde quando se abriram hostilidades contra a orientação liberal do sistema escolar brasileiro.

Dito isto, passemos à análise do projeto conciliador.

\section{UMA OMISSÃO SINTOMÁTICA}

Topamos desde logo com uma omissão de importante valor sintomático. Ao referir-se ao princípio da solidariedade humana inscrito no art. 106 da Constituição da República, o projeto liberal, nas suas três versões, inspirando-se em fórmula mais extensa oferecida à comissão de 1947 por Leví Carneiro, consignou o seguinte tópico:

"A educação nacional (...) coibirá o tratamento desigual por motivo de convicção religiosa, filosófica ou política, ou preconceito de classe ou de raça".

Ora, o projeto conciliador, ao fixar em seu Título I os fins da educação, houve por bem omitir êsse preceito, o qual, a meu ver, constitui em si mesmo uma das notas mais típicas da escola pública democrática. Da escola pública, insisto. 
Porque a escola particular, em virtude das próprias condições que lhe dão vida e alimento, investiga sôbre a classe social do candidato, questiona a respeito da sua religião, verifica-lhe a côr e a nacionalidade, quer saber por vêzes se seus pais são legìtimamente casados, ou se exercem profissões bem vistas na sociedade. Só depois de tudo averiguado é que o caso se decide - pela recusa ou pela aceitação e, nesta última hipótese, não raro com restrições. É direito seu, não o nego, pois dessa atitude seletiva depende, aos olhos da clientela, o próprio prestígio do instituto e, conseqüentemente, a sua sobrevivência. Mas uma coisa é permitir o funcionamento de tais escolas e outra é acoroçoar-lhes a multiplicação à custa das verbas públicas. Pior ainda será decidir que elas passem a constituir a regra no país, descendo a escola pública a representar a exceção. Pois as escolas de segregação, além de agravarem o distanciamento social, aumentam o custo da educação do povo. Na cidade pequena, onde um ginásio bastaria para todos, serão precisos dois ou três, a fim de atender às diversidades de classe social ou de religião. Seria impraticável ou, pelo menos, anti-econômico.

Alega-se em sentido contrário o caso da Holanda. Sim, existem ali quatro rêdes escolares distintas - a estatal (neutra em religião), a neutra livre, a católica e a protestante. Mas a Holanda tem 289 habitantes por quilômetro quadrado e o Brasil tem 7; sua economia é vigorosa e a nossa é o que se sabe; seu povo alcançou um nível cultural elevadíssimo e o nosso tem 50\% de analfabetos. Demais, quando em 1917 a lei estabeleceu o custeio, pelo Estado, das quatro rêdes escolares, já transcorrera para a Holanda um longo passado de ensino estatal de ótima qualidade, que produzira a unificação do povo em tôrno dos princípios liberais.

Dos motivos alegados em favor da escola privada paga pelc Estado, existia um, em si mesmo respeitável: a falta de ensino religioso. Mas, há quase trinta anos, êsse motivo se atenuou por lei que agora se integrou na Constituição Federal, nos seguintes têrmos:

"O ensino religioso constitui disciplina dos horários das escolas oficiais, é de matrícula facultativa e será ministrado de acôrdo com a confissão religiosa do aluno, manifestada por êle, se fôr capaz, ou 
pelo seu representante legal (Const. Federal, art. 168, n. V)."

Não é a solução da Holanda, mas a única ao alcance da nossa pobreza, da nossa dispersão demográfica e do muito que nos resta por fazer em matéria de educação popular. Os Estados Unidos, mais ricos do que nós e mais sinceramente religiosos, se mostram menos pródigos: nós cedemos a sala de aula e o horário para o ensino da religião; êles cedem tão sòmente o horário.

\section{A FAMILIA E O "DIREITO DE EDUCAR"}

Mas prossigamos nos reparos ao projeto conciliador. Seus Títulos II e III, referentes respectivamente ao direito à educação e à liberdade do ensino, transportam para aquêle documento, com ênfase e reiteração, duas acusações assacadas contra o projeto liberal. Ambas improcedentes e injustas:a de que o projeto desconhece o direito da família relativo à educação da prole, e a de que nêle se consagra o monopólio do Estado em relação ao ensino. Êstes dois chavões ganharam popularidade nos meios interessados, cujos porta-vozes os repetem com tanto maior empenho quanto menos conhecem a vida brasileira e as condições do nosso ensino.

No que tange ao direito da família, elogia-se esta fórmula do projeto conciliador: "A educação da prole é direito da família".

Data venia, discordamos, pois o que nos parece exato é que a educação não constitui um "direito" e sim um "dever" da família. Dever de que esta se desincumbirá, a princípio, em seu próprio seio, e, mais tarde, também através da escola.

O direito que efetivamente cabe aos pais é, "por prioridade", o de "escolher o gênero de educação a ser dado aos filhos" - como se infere do texto constitucional brasileiro e como se lê na Declaração Universal dos Direitos do Homem aprovada em 1948, inclusive pelo Brasil. Se, no desempenho dêsse papel, durante os anos iniciais da infância a família é insubstituível, tem esta, a partir dos sete anos, necessidade de recorrer à colaboração da escola. Começa nesse momento a interferência imprescindível do Estado, única entidade com fôrça 
suficiente para, se necessário, compelir a família. Em relação a alguns pais dispensa-se a coerção; mas em nosso meio, infelizmente, a resistência é ainda poderosa. Donde a fórmula liberal, destinada a assegurar o direito da criança e a facilitar aos pais o cumprimento do dever:

"O direito à educação será assegurado: I — pela obrigação, imposta aos pais ou responsáveis, de proporcioná-la às crianças e jovens sob sua responsabilidade; II - pela instituição de escolas de todos os graus, por parte do poder público ou iniciativa particular".

Mesmo depois de escolhido o gênero de escola, é indispensável que prossiga a ação educativa dos pais. O projeto liberal não desconheceu a importância dessa ajuda recíproca, tanto que inseriu entre os seus preceitos a recomendação, endereçada à escola, de fundar órgãos tais como a associação de pais e mestres. Contudo, o esfôrço nesse sentido vem sendo quase sempre baldado. Os depoimentos estão aí, nas cartas jesuíticas dos primórdios da vida colonial, nos documentos coligidos por Primitivo Moacyr, no parecer de Ruy Barbosa, nos relatórios escolares do Império e da República. Tem havido, com efeito, obstáculos enormes à aproximação entre as duas entidades - a família e a escola - mormente na zona rural e nos pequenos povoados, onde até há bem pouco tempo prevalecia a indiferença, senão a hostilidade de parte a parte. De alguns anos para cá, entretanto, sente-se crescer o interêsse por essa aproximação e assiste-se em todo o país, de norte a sul, às mais diversas e promissoras experiências estimuladoras dos contactos, que deve haver, entre os pais e os mestres. Importa, agora, que o incremento das construções escolares, e a conseqüente volta do dia letivo à duração normal proporcionem instalações melhores e horários menos estritos, a fim de que aquêles encontros se regularizem.

À vista de tudo isso, dar acentuação extraordinária ao chamado "direito da família", como faz o projeto conciliador, que por seu Título II gera a impressão de que êsse direito nunca foi reconhecido, é cometer uma injustiça para com a legislação anterior do Brasil e para com as próprias tradições de nossa escola. 


\section{O MONOPÓLIO DO ENSINO}

Houve no passado, e continua a haver no presente, por êsse mundo afora, casos de monopólio do ensino pelo poder público. Mesmo nos Estados Unidos, tão profundamente liberais, o Michigan tentou modificar sua Constituição antes da última guerra, para poder fechar tôdas as escolas particulares: mas a proposta caiu. E o Oregon chegou a aprovar projeto análogo, que foi, todavia, invalidado em 1925 pela Côrte Suprema norte-americana. Êste alto Tribunal declarou então: "a teoria fundamental de liberdade, sob a qual repousa o govêrno dêste país, exclui qualquer poder geral do Estado, de padronizar seus filhos obrigando-os a aceitar tão sòmente o ensino dos professôres oficiais". O Brasil considera o ensino uma função do Estado, mas nunca o colocou sob monopólio, tanto que um levantamento estatístico de 1958 mostra que $12 \%$ dos alunos de curso primário, $60 \%$ dos de curso médio e $58 \%$ dos de curso superior faziam seus estudos, em nosso país, freqüentando escolas particulares; e sabemos que seus certificados e diplomas gozam das mesmas regalias atribuídas aos equivalentes documentos oficiais. Tudo isso está fielmente consignado, embora com louvável singeleza, na Constituição vigente, ao declarar esta, em seu art. 167, que "o ensino dos diferentes ramos (...) é livre à iniciativa particular, respeitadas as leis que o regulem".

A afirmação inicial dêsse artigo foi a fórmula que o projeto liberal transcreveu como definição autêntica da atitude do poder constituinte de 1946. Quanto às leis que regulem o ensino particular, o mesmo projeto lhes traçou os contornos com a generalidade e amplitude que convêm a um plano nacional. E mais não seria preciso.

Reitero, pois, a respeito do alegado "monopólio", o reparo já feito ao chamado "direito de educar". O projeto conciliador foge à realidade ao usar, como usa, tanta ênfase para levar o Estado a proibir a si mesmo o favorecimento do monopólio do ensino; e seu Título III, que nada acrescenta nem restringe ao que está dito em outros tópicos, não sòmente é supérfluo, mas também, por sua ambigüidade, amesquinha injustamente o passado educacional brasileiro. 


\section{DOS PRINCÍPIOS À REALIDADE}

Todavia, quando o projeto conciliador dá destaque e ressonância àquilo a que chama "direito de educar", assim como à proibição do monopólio, o alvo a que realmente visa é de natureza concreta: são as bôlsas de estudo apresentadas globalmente na alínea II do art. $3 .^{\circ}$ e minudenciadas depois, através de cinco extensos parágrafos do art. 82. Neste tópico, a divergência entre os dois projetos - nula quanto ao princípio, pois que ambos o consignam - reside tôda na amplitude de sua aplicação e nas condições dos órgãos responsáveis pela distribuição do benefício. Êstes órgãos são os Conselhos de Educação do projeto conciliador, a respeito dos quais expressarei mais adiante o meu pensamento.

Mas vejamos as bôlsas de estudo. Pode-se dizer, a esta altura, que são elas, por seu volume e destinação, um novo divisor das águas entre os dois projetos; ou, mais precisamente, a barreira que separa duas políticas educacionais antagônicas. A primeira - a mais antiga, pois que vem do passado distante - tem propósitos discriminativos e pretensões aristocráticas; quer formar uma elite de doutores e pouco se lhe dá que o homem do povo fique na situação em que se acha. Foi a política de Thiers em 1849, quando, defendendo ao lado do abade Dupanloup a chama "liberdade do ensino", exclamou: "Instruir o pobre é acender o fogo debaixo de uma panela vazia"; e foi igualmente, trinta anos depois, a política do Senado brasileiro ao combater a modernização da escola primária: certas matérias (disse Oliveira Junqueira) "talvez não sejam convenientes para o pobre; o menino pobre deve ter noções muito simples"; ao que o senador Teixeira Júnior acrescentou: "A grande massa deve ter apenas instrução elementar". O Brasil de hoje, ao que parece, pensa um pouco diferente: para que os jovens das "boas famílias" tenham ginásio, colégio e faculdade - tudo isso à custa do Estado - a "grande massa" não deve ter instrução nenhuma.

A segunda política - a política realmente democrática é a que, sem descurar os graus mais altos do ensino, indispensáveis à vida nacional, concentra o máximo dos recursos orçamentários no desenvolvimento da escola comum, e clama por um ensino primário mais penetrante, mais difundido e de 
atuação cada vez mais prolongada. Ensino primário em tais condições, sòmente a escola oficial poderá realizá-lo, desde que o poder público se disponha a mobilizar, em benefício da instituição, dotações muito mais generosas do que as que até hoje lhe tem proporcionado. O Brasil, com efeito, vem tomando nestes últimos decênios uma orientação anti-democrática, cujos propósitos se retratam na frieza dos algarismos do orçamento educacional: 43,2\% para atender pèssimamente a 4 milhões de crianças inscritas na escola primária e deixar sem escola outros 4 milhões; $56,8 \%$ para satisfazer a $850 \mathrm{mil}$ adolescentes e jovens, os quais, tendo já recebido os benefícios da educação comum, de grau elementar, querem também, à custa do erário público, o ensino dos outros graus. Verdadeira iniqüidade social!

Estamos numa encruzilhada e chegou, portanto, o momento de decidir. Antes de fazê-lo, importa ao poder público indagar se realmente convém - como resultará do projeto conciliador - aumentar os privilégios educacionais de uns poucos, mesmo que com isso se agrave a miséria cultural da grande maioria, ou se, ao contrário, devemos mudar de rumo e cumprir sem subterfúgios, com sinceridade integral, o texto da Carta Magna vigente, que diz:- "a educação é direito de todos".

\section{SISTEMAS DE ENSINO - O CASO DOS "ESTAGNADOS"}

Deixando para o fim o Título referente à administração (ponto nevrálgico do projeto!), examinemos a seguir o Título $\mathrm{V}$, que dispõe sôbre os sistemas de ensino. Neste particular a proposta conciliatória em quase nada se afastou da anterior e, quando o fêz, foi para introduzir inovações pouco felizes, pois que dentre elas uma é inconveniente, outra supérflua, duas ficariam bem em outros Títulos e a derradeira é de interêsse duvidoso.

É inconveniente e também absolutamente inútil aquilo que pede o art. 17: que os Estados comuniquem ao Ministério da Educação "a instituição e o reconhecimento de escolas de grau primário". Saberão os ilustres autores do projeto o que isso representa como trabalho burocrático? Uma enormidade! E sem a mínima vantagem, pois a colheita de dados estatísticos, que é o que pode interessar, compete ao IBGE. Mi- 
nha sugestão é simplesmente esta: cancelar, no art. 17, a expressão "de grau primário". O art. 19, segundo o qual não haverá distinções, para qualquer fim, entre os estudos realizados em estabelecimentos oficiais ou particulares reconhecidos - é supérfluo. O art. 20, sôbre diversificação de métodos de ensino e encorajamento de experiências pedagógicas, está implícito no art. 92, que admite escolas experimentais: supérfluo, igualmente, e de qualquer forma deslocado neste Título. $\mathrm{O}$ art. 21 inclui uma inovação perigosa e de duvidoso interêsse:- a possibilidade da instituição de "escolas públicas autônomas", mantidas por fundações cuja dotação provenha do erário público, e que possam cobrar anuidades. Por esta última cláusula (a não gratuidade) se infere que tais escolas não serão de grau primário... Mais uma expressão concreta do propósito de favorecer o crescimento do sistema escolar discriminativo à custa do orçamento nacional.

Finalmente, reclama destaque o art. 18, que diz:

Art. 18 - Nos estabelecimentos oficiais de ensino médio e superior será recusada a matrícula ao aluno gratuito reprovado mais de uma vez em qualquer série ou conjunto de disciplinas.

Êste dispositivo vem restabelecer no ensino oficial brasileiro aquilo que na gíria acadêmica se chamou "jubilação". Aparece, embora em têrmos diferentes, nas três versões do projeto liberal e agora no projeto conciliador, que o ampliou para alcançar o ensino médio. Trata-se de preceito utilíssimo. Contudo, os têrmos em que o redigiram tanto as comissões ministeriais como os autores do projeto conciliador, o tornam pràticamente inoperante. Numa apuração estatística a que procedi em 1958 na Faculdade de Direito de São Paulo, cuja matrícula era então de cêrca de 2.000 alunos, verifiquei existirem ali 269 alunos (isto é, 13\%) que estavam retidos na mesma série pela terceira vez. Dêsses "estagnados", como os chamei, 126 haviam feito o vestibular 3 a 9 anos antes da data do inquérito; 136 o haviam feito 10 a 20 anos antes; e existiam alunos cuja prova de ingresso era ainda mais antiga, datando de 21, de 22, de 23 anos. Mas o recordista do grupo prestara seu vestibular fazia já 27 anos. Em outros institutos da Universidade de São Paulo também ocorrem "estagnados", embora em menor proporção. E na Universidade do 
Brasil, segundo declararam representantes da UNE quando perante êles analisei o fenômeno, é grande o contingente dêsse tipo anômalo de aluno, cuja grei se avoluma principalmente (dizem os informantes) por funcionários que, morando nos subúrbios, querem das faculdades tão sòmente o privilégio do restaurante, onde o almôço é quase de graça.

Pois bem: dos 269 estagnados da Faculdade de Direito, que ano após ano ocupam lugar - menos nas salas de aula que nos empregos ou no pátio das Arcadas, nenhum poderia ser jubilado com apoio na fórmula proposta. $E$ isto porque 0 verdadeiro "estagnado", embora se inscreva no comêço de cada ano letivo (salvo algumas interrupções); embora compareça a uma ou outra aula, e se submeta por esporte a alguns exames parciais - nunca ou quase nunca é reprovado, porque só de longe em longe presta exame final. O texto sugerido na última versão do projeto liberal (a dos nove educadores) e a que dou agora um pequeno retoque, parece-me preferível. É o seguinte:

VIII - Eliminação dos alunos que forem reprovados mais de uma vez na mesma série ou que, pelo não comparecimento injustificado aos exames, forem considerados, pela Congregação, incapazes de estudos regulares.

Seja qual fôr a redação anotada (nunca, entretanto, a do projeto conciliador) o certo é que êste dispositivo está evidentemente deslocado no Título V. Deve figurar na parte relativa a cada grau de ensino. Dito isto, passemos a considerar o Título VI, que cuida da educação primária.

\section{DA EDUCAÇÃO PRIMÁRIA}

Haverá realmente necessidade de fixar em lei os "fins" do ensino primário? Os autores do projeto liberal entenderam que não; os do projeto conciliador foram de opinião oposta. Mas o fim que êstes últimos atribuiram àquele ensino, é também o do ensino médio "comum". O art. 26 usa a expressão "classes especiais" para rotular aquilo que usualmente designamos por classes ou escolas de "ensino supletivo". O parágrafo único do art. 27 cria uma sanção contra os pais que não exerçam o "direito" de educar: nega a êsses pais 
quaisquer empregos em repartições oficiais, em autarquias, em emprêsas concessionárias de serviços públicos. É mais uma coerção do poder público sôbre os pais refratários, a acrescer-se ao inoperante art. 246 do Código Penal. O que sucede, entretanto, é que os pais refratários não são êsses a que alude o art. 27: são gente mais modesta, da classe dos trabalhadores rurais; e a ação, que sua rebeldia reclama, deve ser muito mais de catequese que de intimidação.

O parágrafo único do art. 28 representa uma inovação: admite que as emprêsas industriais, comerciais ou agrícolas, obrigadas pela Constituição a criar escolas para os filhos de seus servidores, possam desincumbir-se disto mediante contribuição em dinheiro, ou bôlsas, em benefício do ensino primário local. Só a experiência dirá sôbre a eficácia desta medida. Assinalo-a, todavia, como um passo feliz - embora de pequeno alcance - para afastar-nos da "escola de classe" instituída no art. 168 da Constituição.

"Há vinte anos atrás (escrevi em 1936) causava maravilha ao visitante estrangeiro encontrar na mesma sala de aulas do nosso grupo escolar - um ativíssimo cadinho de socialização e democratização - o filho do sapateiro, o do verdureiro, o do médico, o do industrial, reunidos nas lições e brincando juntos no recreio. Era a "escola comum" que, antecipando-se à evolução da Europa, Cesário Mota e Caetano de Campos haviam realizado entre nós". Na mesma categoria de institutos que, por sua especificidade, tendem a produzir quistos classistas, estão as escolas para filhos de funcionários, ou para filhos de militares, ou para filhos desta ou daquela colônia estrangeira. Quanto mais os seus alunos cultivem o espírito de classe trazido do lar e reforçem a coesão dentro do seu próprio grupo, tanto mais irão resistir, posteriormente, à "integração no meio social", a que se refere o art. 24 do novo substitutivo.

Outro defeito da Constituição Federal assinala-se na forma pela qual é fixada por ela a obrigatoriedade escolar:- em têrmos de grau de ensino, não em têrmos de idade. Concluído o curso primário (o que pode ocorrer aos dez ou onze anos), está o menor isento da compulsão constitucional e, se os pais não se interessaram por mantê-lo no estudo, permanecerá desocupado até a idade de quatorze anos, que é quando a mesma 
Constituição lhe permite empregar-se. Êsse período vazio, de três ou quatro anos, representa o "hiato nocivo na vida legal dos menores", que denunciei em 1932 e que até hoje não pôde ser preenchido. Convém, por certo, modificar na primeira oportunidade o texto constitucional, a fim de levá-lo a dizer que o ensino ("ensino" apenas, sem referência ao grau) será obrigatório dos 7 aos 14 anos. O remendo agora proposto no projeto conciliador - ou seja, o acréscimo eventual do quinto e sexto ano ao curso primário - coincide com o remendo inserido antes no projeto liberal: as séries terminais de uma escola terão conteúdo igual ao das séries iniciais da outra; mas naquela serão de grau "primário", e nesta, de "grau médio". Há, todavia, uma diferença entre os projetos. Segundo o anterior, os dois anos acrescidos ao curso primário equivaleriam às duas séries iniciais do curso médio; de acôrdo com o novo, deverão equivaler apenas à primeira série média. Não percebo o motivo desta desvalorização; tanto mais que a articulação entre os dois cursos se fará mediante exame.

Quanto aos mestres primários, nenhuma inovação. Haverá dois níveis, a saber: regentes, formados no ciclo ginasial, e professôres primários, no ciclo colegial. Para os institutos de educação, de nível mais alto, irão os professôres primários que pretendam cursos de especialização ou aperfeiçoamento.

\section{DO ENSINO DE GRAU MÉDIO}

E passamos ao ensino de grau médio - pedra de toque das reformas escolares. O projeto liberal não sofreu neste setor nenhuma alteração de importância, pois o novo projeto atendeu aos seis pressupostos em que aquêle se havia baseado, a saber:-

$\left.1^{\circ}\right)$ a necessidade de prolongar-se até os 18 anos o ensino comum, de formação geral;

$2^{\circ}$ ) a inconveniência de se determinar, antes dos 13 anos, o rumo profissional do adolescente;

$3^{\circ}$ ) a vantagem de se elevar aos olhos das novas gerações o prestígio e a dignidade de tôdas as formas de trabalho;

4.. ) a existência de diferenças individuais; 
5. ${ }^{\circ}$ o propósito de instituir combinações curriculares adaptadas, quanto possível, à personalidade de cada aluno;

6. ${ }^{\circ}$ o valor ainda precário das técnicas de orientação profissional, o que obriga por vêzes a reconsiderar os seus conselhos.

Em obediência a tais diretrizes, em cada ciclo do ensino médio (o ginasial e o colegial) haverá disciplinas e práticas; umas obrigatórias, outras optativas - aquelas fixadas pelo Conselho Federal, estas pelos Conselhos Estaduais, que as relacionarão para a escolha dos estabelecimentos. De acôrdo ainda com as mesmas diretrizes, o currículo das duas séries iniciais do $1 .^{\circ}$ ciclo será comum a todos os cursos de grau médio, no que se refere às matérias obrigatórias. Isto significa que as mencionadas séries irão funcionar como "classes de orientação", nas quais cada aluno, para achar o seu rumo, se consultará a si mesmo e será observado pela família e pelos mestres. É respeitado o princípio das equivalências, admitindo-se conseqüentemente que o aluno se transfira do curso secundário (curso de tipo acadêmico) para qualquer outro, de natureza técnica, ou vice-versa, mediante adaptação.

Constitui novidade do projeto conciliador a recomendação de se adotar para os cursos noturnos de grau médio (e por que não também para os de grau superior?) uma estrutura própria, segundo normas gerais a serem baixadas pelas autoridades do ensino. Esta novidade, não precisamos dizê-lo, só será boa se se expressar pela redução do horário de cada dia, compensada com o aumento no número de séries do curso. Quanto a isso o projeto não se definiu.

Disciplinando os exames, o projeto liberal havia dito apenas isto: "prestação de exames perante professôres do próprio estabelecimento e com fiscalização oficial". Era o que bastava para uma lei geral. O projeto conciliador, entretanto, complicou as coisas: assegura "autoridade de julgamento" ao professor, embora declare, a seguir, que os exames serão prestados perante uma comissão.

Apreciemos agora o problema do magistério. Há aqui, com base na Constituição, uma grave diferença de nível entre os dois sistemas - o oficial e o privado. Para chegar a professor de escola média oficial, deve o candidato passar, 
primeiro, por formação especial (Faculdade de Filosofia ou, segundo o caso, um curso técnico) e, a seguir, por um concurso de títulos e provas. É, aliás, exigência constitucional e está certíssimo. Mas ao magistério particular não se impõe nem formação especial, nem concurso. Também consta da Constituição. De sorte que, do candidato ao cargo de professor em escola média privada, só se exige prova de registro no órgão competente - o Ministério da Educação (art. 86) o qual, "enquanto não houver número bastante de licenciados, e sempre que se registre essa falta", se contentará com um exame de habilitação perante Faculdade de Filosofia "particular ou oficial" para tanto credenciada pelo Conselho Federal de Educação (art. 102). "Particular ou oficial" — diz textualmente o dispositivo do projeto. Lapso ou intenção? Mas a ordem de colocação pouco importa. O fato é que se adia para "depois que houver licenciados", e isso mesmo com a possibilidade de se interromper "sempre que se registre a falta", o provimento das cátedras de grau médio do ensino particular por professôres regularmente formados. A Constituição Federal, é verdade, não exige concurso para o professorado secundário particular, como tampouco exige prova de suficiência. Mas não seria o caso de se despertar nos institutos privados, mediante algumas vantagens, a ambição de aperfeiçoar o respectivo corpo docente? O projeto Mariani lembrara atribuir-lhes "as prerrogativas que a lei confere às escolas oficiais" - prerrogativas que não eram muitas e diziam respeito essencialmente à fiscalização - desde que, entre outras coisas (melhoria de vencimentos e estabilidade para os professôres), dessem provimento aos cargos docentes através de concurso. Não se percebe no projeto de agora a mínima tendência nesse sentido. Deseja êle, ao contrário, dar tudo de mão beijada ao sistema escolar privado, sem a menor sugestão para estimulá-lo ao aperfeiçoamento.

Todavia, no tocante ao corpo docente, a situação dêsse sistema está longe de ser tranquilizadora. Temo-lo mostrado por meio de apurações de concurso vestibular e, mais recentemente, pelo exame dos títulos com que seus mestres figuram na estatística oficial. Em 1956 funcionavam no país 2.321 cursos médios, dos quais $72 \%$ eram de caráter particular. $\mathrm{O}$ preparo dos professôres desta categoria não havia sido verifi- 
cado mediante concurso de títulos e provas (como no magistério oficial), e sim apenas pelo chamado "exame de suficiência". Eis aqui as credenciais constantes da estatística, segundo a ordem numérica decrescente: normalistas, 9.222; licenciados, 7.748; sem diploma, 5.625; sem declaração, 3.716. O que há de melhor é, por certo, o título de licenciado; mas nêle, apenas, não poderá confiar quem conheça o valor das dezenas de Faculdades de Filosofia improvisadas nestes últimos anos em nosso país, à custa de magistério de emergência. Uma lástima - pode-se dizer de algumas delas. Por análogo motivo o diploma de normalista inspira moderado entusiasmo mesmo para o exercício do magistério primário. Os "sem diploma" e os "sem declaração" guardam para si o seu segrêdo. Fica tudo, afinal, entregue ao critério dos diretores ou das entidades mantenedoras de estabelecimentos, algumas das quais (seja dito em sua honra) sabem selecionar honestamente o respectivo corpo docente. Mas não são a regra.

Voltemos, entretanto, ao professorado das escolas privadas de grau médio. Em 1956, num concurso efetuado em São Paulo para o provimento de 217 vagas de institutos oficiais, inscreveram-se, entre outros, 268 licenciados e 159 normalistas. As provas, ao que se disse, foram fáceis, o que não obstou a que saíssem inabilitados $60 \%$ dos licenciados e $73 \%$ dos normalistas. O resultado é sugestivo.

Um artigo do projeto liberal (última versão) consigna esta norma que nos parece constituir incentivo de grande valor:

Art. 14 - Os serviços educacionais dos Estados e do Distrito Federal, atendendo aos critérios fixados pelo Conselho Nacional de Educação, classificarão as escolas de grau médio integrantes dos respectivos sistemas, para conhecimento dos pais e responsáveis.

Norma equivalente, em relação às Faculdades de Medicina, posta em execução nos Estados Unidos, reformou em poucos anos, da água para o vinho, o ensino médico norte-americano. Mas o projeto conciliador entendeu acertado cancelar êsse art. 14. Em nossa opinião (como escrevíamos a propósito do jubileu de prata da Faculdade de Filosofia da Univer- 
sidade de São Paulo), impõe-se ao Brasil caminhar no sentido de garantir, em futuro próximo, aos licenciados em filosofia ciências e letras, o monopólio da profissão, como ocorre, por exemplo, aos médicos e aos advogados.

\section{DO ENSINO SUPERIOR}

Poucos reparos faremos ao Título IX, que trata do ensino superior. Foi atendida, embora de maneira confusa e contraditória, a sugestão expressa no relatório que acompanhou o projeto dos educadores, sôbre a distinção entre os cursos destinados a formar profissionais e os outros cursos, para que a futura lei regule sòmente aquêles, abstendo-se de imiscuirse nos demais. A contradição está em que o projeto fixou, desnecessàriamente, normas a respeito dos cursos de pós-graduação.

O projeto prevê o exame de Estado para os portadores de diplomas profissionais: esta importante inovação encolhe-se modestamente no parágrafo único do art. 62, encoberta por detrás da prescrição do registro de diplomas. Prevê, mas não vai por diante: diz apenas que a lei poderá "exigir a prestação de exames e provas de estágio perante os órgãos de fiscalização e disciplina das profissões respectivas". Uma lei que diz que outra lei poderá exigir, é igual à lei que não diz nada!

Para o problema dos currículos mínimos, quatro soluções haviam sido propostas, na seguinte ordem decrescente de centralização: a) fixação do currículo mínimo pelo Congresso; b) fixação pelo Conselho Nacional, homologada pelo Ministro; c) organização pelas congregações e aprovação pelo Conselho Nacional (ou Universitário) com homologação do Ministro; d) organização livre pelas Congregações. O projeto liberal decidiu-se pela solução "c", muito próxima da descentralização total; mas o projeto conciliador preferiu a solução "b", mais próxima da completa centralização. Terá o novo Conselho Nacional, como o projeto em exame o estruturou, idoneidade técnica para organizar os numerosos currículos mínimos do ensino superior brasileiro? Não o creio.

O provimento das cátedras se dará por concurso ou, a juízo da congregação, mediante transferência de candidato que haja passado por aquela prova. Neste caso se efetuará 
antes, um concurso de títulos. Para inscrever-se em concurso de títulos e provas, deve o candidato apresentar diploma adequado ou prova de haver realizado ou publicado "obra" relacionada com a cadeira. Que porta elástica, esta obra "publicada" ou "realizada"! E como irão prevalecer-se dela, para a sua gente, as Faculdades de baixo nível! Dos têrmos do projeto se depreende que, para a inscrição, os institutos não poderão exigir títulos adicionais - o de doutor, o de livre docente, como alguns já estão exigindo. Não será isto lamentável? Findo o concurso, cujas provas e formalidades são iguais às de hoje, haverá um único resultado positivo:- a indicação do vencedor para ocupar a cadeira. Os outros candidatos, mesmo que aprovados, não receberão nem grau nem título. Digna de acolhimento essa inovação, explicável por fato sobejamente conhecido: o longo cortejo de livres docentes de qualidade inferior, produzidos pela benevolência das bancas, e que vão depois pleitear supostos direitos.

Há esta importante novidade: quando um professor de faculdade começar a faltar muito, ou mostrar-se omisso na execução do programa, qualquer interessado poderá requerer seja êle afastado temporàriamente do cargo. Por outro lado, foram esquecidas as agremiações acadêmicas, de absoluta necessidade nos institutos universitários. É indispensável conservá-las na legislação, com o devido comedimento, a fim de que não lhes seja possível se transformarem em instrumentos de demagogia interna para uso das ambições de grupos docentes - como tem acontecido em certos países latino-americanos.

\section{A UNIVERSIDADE E O ESTADO}

De modo geral, o projeto conciliador procura excluir o poder público do campo educacional e se inclina no sentido de tudo entregar a Conselhos cuja origem e provável composição (segundo se verá) não inspiram muita fé, nem podem dar esperança de neutralidade. Isto ocorre especialmente nos domínios do ensino superior.

Sem embargo do contido no art. 171 da Constituição Federal, que atribui às unidades federadas competência privativa para organizarem seus sistemas de ensino, o projeto dispõe de modo diverso. O Estado que pretenda criar uma uni- 
versidade, há de conferir-lhe necessàriamente a natureza jurídica de fundação ou autarquia; há de atribuir a elaboração e reforma dos respectivos estatutos a órgãos universitários autônomos e, a seguir, ausentar-se da vida da instituição, a fim de que desta última só cuidem o Conselho Universitário, o Conselho Estadual (para aprovar os estatutos) e o Conselho Federal (como fiscal supremo). Só lhe resta - ao Estado mantenedor - a função de pagar as despesas, e isto mesmo sem intervir na distribuição da verba global que destinará à universidade. O problema da aprovação dos estatutos merece dois reparos. O primeiro é que, tratando-se de universidade estadual (e só de universidade estadual), os estatutos independem (segundo o projeto) de aprovação federal, muito embora os diplomas da universidade devam ter validade nacional. O segundo é êste: o órgão que em suprema instância aprova os estatutos de tais universidades, é o Conselho Estadual de Educação, integrado pelos representantes dos três graus de ensino - o primário, o médio e o superior - cuja maioria (se o Govêrno do Estado não se precaver) se constituirá de delegados do ensino privado.

A injustificável medida de exceção, que isenta as universidades estaduais de submeterem os respectivos estatutos ao Conselho Federal, tem o seu trôco, pois que êste último permanecerá vigilante, possuindo já agora (se o projeto passar) uma arma terrível em suas mãos:- a intervenção federal na universidade. De fato, segundo o art. 72 do projeto, o Conselho Federal de Educação, após inquérito administrativo,

"poderá suspender, por tempo determinado, a autonomia de qualquer universidade, oficial ou particular, por motivo de infringência desta lei ou dos próprios estatutos, chamando a si as atribuições do Conselho Universitário e nomeando um reitor pro-tempore.

É hipótese não prevista na Constituição brasileira, esta da intervenção em instituto universitário estadual por um órgão federal. órgão que se integrará por vinte e um representantes - um de cada Estado - além de nove membros da confiança do Presidente da República. Será como se o Brasil inteiro mandasse ocupar certa área territorial de uma 
unidade federada e destituisse, ali, as autoridades nomeadas pelo Governador. É, aliás, o que o art. 72 do projeto conciliador promete.

Dissolvido o Conselho Universitário, suas funções serão avocadas pelo Conselho Federal sediado no Rio (ou talvez em Brasília); o Magnífico Reitor receberá convite telegráfico para deixar o cargo, devendo passá-lo ao Reitor-interventor, que porá, certamente, homens de sua confiança nos postoschave da instituição, tais como secretaria geral, chefia da contabilidade, tesouraria. E a universidade do Estado ficará em situação análoga à de suas irmãs de certas repúblicas latino-americanas, quando infelicitadas pelos ditadores.

O Título IX, que estamos examinando dá a nítida impressão de que seus autores, não depositando confiança nas entidades mantenedoras, resolveram encerrar a universidade numa fortaleza inexpugnável, de cuja porta deram a única chave ao Conselho Federal de Educação. Ora, a velha doutrina universitária do "esplêndido isolamento" vem sendo posta abaixo em cada um dos países que outrora a adotaram, à vista dos maus resultados produzidos e, mais ainda, em virtude das novas condições criadas pela evolução social e econômica.

Para contar dos maus resultados, eis como se expressou, em 1956, autorizado jornal híspano-americano a propósito de uma das muitas crises universitárias de seu país:

"Já assinalamos que a burocracia está devorando a universidade; que na universidade não se estuda; que os alunos não freqüentam as aulas; que os exames costumam ser uma comédia; que das classes universitárias não saem profissionais devidamente preparados; que, salvo exceções, ali não se ensina nem se pesquisa com seriedade (...); que não raro as cátedras se multiplicam ou são desdobradas com o único propósito de favorecer a determinadas pessoas; que, se entre os alunos causam estrago a desordem e a demagogia, entre os professôres prosperam os interêsses pessoais ou de grupo".

O sistema universitário brasileiro nasceu ontem e não 
chegou, felizmente, ao grau de descalabro que, talvez com exagêro, o jornalista hispano-americano descreveu em seu país. Mas podemos caminhar para lá se não tomarmos precauções. E entre as medidas profiláticas se alinha, não a muralha chinesa do projeto, que divide e gera a desconfiança, mas o contacto amistoso e compreensivo entre a universidade e a organização que a mantém, seja esta a União, o Estado ou uma entidade particular. O prestigioso jornal que acabamos de citar refere-se a duas formas dêsse contacto, quando, prosseguindo em sua crítica, declara:

"Já lembramos também que ao país compete, no tocante à universidade, uma função fiscalizadora e de vigilância, pois afinal de contas a universidade se mantém à custa da economia do país".

E adverte: "A autonomia não deve funcionar como uma cortina de fumaça sob cuja proteção a universidade se subtraia ao cumprimento de seus deveres".

No elenco de tais deveres o importante periódico incluiu (como antes dêle o havíamos feito) o de debater pùblicamente a proposta orçamentária de cada ano e bem assim o de divulgar a universidade, de maneira sistemática, o relatório de seus trabalhos e a prestação de suas contas. De nada disto (afora a prestação de contas formal) se ocupou o novo projeto. Uma conhecida instituição católica do Canadá, a Universidade Laval, manifestando-se a respeito dêste assunto por um dos seus líderes, assim disse em 1952:

"Verificar a despesa, exigir relatórios, pedir que cada requisição seja justificada, abstendo-se entretanto de imiscuir-se de maneira indevida nos assuntos das universidades (...) - tudo isso é da competência do Estado" (J. Desy).

Ao que outro representante da mesma Universidade, Monsenhor Alphonse Marie Parent, acrescentou em 1956:

"Precisamos de maior ajuda financeira a fim de podermos fazer melhor; mas devemos provar nossa capacidade para fazê-lo antes de obter aquela ajuda".

Encerrando as citações ligadas ao assunto, seja-nos per- 
mitido recordar, afinal, a famosa declaração conjunta dos Vice-Chanceleres (isto é, dos Reitores efetivos) das universidades da Grã-Bretanha, ou seja o mais alto órgão universitário de um país - conhecido por sua velha tradição contra a ingerência do Estado na vida dos institutos de ensino superior. Eis o texto do manifesto coletivo, cuja publicação data de julho de 1946:

"As universidades concordam inteiramente com a opinião de que o Govêrno tem não sòmente o direito, mas o dever de certificar-se de que cada setor de estudos que, no interêsse da nação, deve ser cultivado na Grã-Bretanha, está de fato sendo cultivado de maneira satisfatória no sistema universitário, e que os recursos postos à disposição das universidades estão sendo empregados com a devida consideração à eficiência e também à economia".

Aí está, sem nenhuma dúvida, a tese digna de acolhimento. O Estado (que é, em quase todo o mundo, cada vez mais, a. verdadeira entidade mantenedora do ensino universitário) deve respeitar a universidade e, dentro do seu alcance, procurar ajudá-la nos seus diferentes setores de trabalho, inclusive no de pesquisa desinteressada. A universidade, por sua vez, abstendo-se de enclausurar-se na tradicional tôrre de marfim, que os novos tempos não mais toleram, há de justificar perante o Estado o destino que deu aos recursos recebidos, e bem assim os esforços que fêz para alcançar os seus objetivos. O novo projeto não cuidou dêsse importante aspecto da organização universitária. Ao contrário, graças à estrutura administrativa que engendrou, ergueu uma muralha entre as duas entidades, como se Estado e universidade fôssem e devessem ser inimigos irreconciliáveis.

\section{O CONSELHO ESTADUAL DE EDUCAÇÃO}

Ousamos declarar, com o devido respeito, que, na parte relativa aos Conselhos de Educação, os ilustres autores do novo projeto cometeram erros sôbre erros.

Começaram por determinar que a escolha dos conselheiros seja feita mediante eleição, em que votará todo o profes- 
sorado. O certo, entretanto, será a livre nomeação pelo Chefe do Govêrno, quer no Estado, quer na União. Dadas as funções que vão desempenhar, os conselheiros hão de ser técnicos de cultura e de comprovada experiência; e não cremos que através de eleições a escolha corresponda a essa necessidade. Vão vencer os mais afoitos em apresentar-se, os mais desenvoltos em cabalar, os mais férteis em prometer. E como, segundo o projeto, a reeleição é livre, êsses mesmos candidatos - afoitos, desenvoltos e férteis - vão também se revelar fáceis em concessões, graças às quais poderão perpetuar-se no cargo. Será preferível que se escolha cada conselheiro da mesma forma pela qual o homem sensato escolhe o médico da família ou o arquiteto que lhe vai construir a residência; isto é, indagando, consultando, refletindo.

Outro êrro é a organização classista dada ao novo Conselho. Graças à futura reforma, iremos ver (se o projeto passar) esta coisa inédita no país: os dois grupos de mestres os do ensino público e os do ensino particular - mobilizados pela primeira vez um contra o outro, impregnados do sentimento de classe e marchando para a conquista dos postos de comando dos sistemas escolares. Quais as vantagens dêsse tipo de competição? A despeito da ausência de leis, os dois magistérios vêm tendo representação adequada nos órgãos orientadores do ensino; mas, uma vez nomeados, os respectivos representantes perdem a lembrança de sua origem para só pensarem em defender os interêsses da escola e da educação.

Da forma desacertada de escolha - a eleição, - e da inconveniência classista, resulta um terceiro êrro - o da base para a fixação das proporções dos eleitos. Será (diz o projeto) o da proporção entre estabelecimentos públicos e estabelecimentos privados. Daí nossa dúvida:- "Que é um "estabelecimento"? Parece-nos que esta expressão se confunde com aquilo que o I.B.G.E. designa por "unidade escolar" (e contra a qual temos reclamado). Se assim se decidir, tanto será "estabelecimento" a escola isolada de 30 crianças como o grupo escolar de 2.000 alunos; o ginásio de 4 classes como o colégio 10 vêzes maior; a faculdade de direito gerada de súbito na cabeça de um prefeito municipal, como os seculares Cursos Jurídicos de São Paulo ou do Recife. Não se indaga do volume da matrícula, não se pergunta se o corpo docente 
é efetivo ou interino (nas novas escolas superiores há mais de 4.000 interinos), não se distingue entre faculdade apenas autorizada e faculdade já reconhecida. Tudo é "estabelecimento" e, como tal, influi na proporção de representantes e fornece eleitores.

E qual será o provável resultado das eleições, tendo em vista aquilo que o projeto estipula? Não é difícil prevê-lo, conheciđas às estatísticas de "estabelecimentos" de cada grau, Estado por Estado. Dos representantes do grau primário a maioria caberá ao ensino oficial; mas, entre os dos graus médio e superior vencerá o ensino privado. Em outros têrmos, em todos os Conselhos Estaduais irão preponderar os representantes do magistério privado. A não ser que o poder público estadual se anime a estabelecer o equilíbrio entre as duas fôrças, engrossando as fileiras da minoria através das nomeações de livre escolha. É, enfim, a "política escolar" que se vai oficializar no país, prelúdio, talvez, de uma "guerra das escolas".

Resta ainda uma dúvida sôbre os Conselhos Estaduais e, se a ela me refiro, é a fim de provocar o parecer dos nossos constitucionalistas. A Constituição de 1934 previa Conselhos de Educação para as unidades federadas; mas a de 1946 silenciou sôbre o assunto. A comissão que ofereceu ao Ministro Mariani o projeto de 1948, admitiu a conveniência de se formarem êsses órgãos, nos Estados (de modo naturalmente diverso do de agora); mas, não encontrando base constitucional para prescrevê-lo, sugeriu uma simples recomendação:-

"Art. 73 -- Nas suas relações com os poderes locais, a União estimulará: a) a criação de Conselhos locais de Educação..."

Todavia, nas versões posteriores entendeu-se preferível cancelar êsse tópico inteiramente platônico. Pergunto, entretanto:- Poderá a União, no silêncio da Carta Constitucional, impor aos Estados que criem determinado órgão administrativo? Que, além de criá-lo, escolham de certa forma os seus integrantes? Que dêem ao referido órgão estas ou aquelas atribuições? Veio-me ao espírito a idéia de uma reação de rebeldia nos Estados objetivada pela não criação do Conselho. Examinando o projeto, verifico que também êle prevê 
essa hipótese e vai além, pois indica desde logo a solução: o Conselho Federal, nesse caso, chamará a si tôdas as atribuições do Conselho Estadual que se não criou. Tôdas: as pedagógicas e as administrativas e, entre estas, as relativas às finanças estaduais, pois, nos têrmos do projeto, ao Conselho Estadual (e não mais à Assembléia) caberá resolver sôbre a aplicação dos recursos estaduais à educação (art. 81). É como se vê, mais uma intervenção branca nos negócios do Estado.

\section{CONSELHO FEDERAL DE EDUCAÇÃO}

Passemos, enfim, ao derradeiro capítulo de nosso estudo, o que se refere ao Conselho Federal de Educação, órgão supremo na direção de todo o ensino brasileiro. Tem êsse Conselho Federal a mesma fisionomia classista do Conselho Estadual, complicada com a idéia da representação regionalista. $\mathrm{E}$ seu funcionamento se entorpece pelo número excessivo de conselheiros, assim como pela desnecessária distribuição dêsses conselheiros em câmaras distintas, rígidamente pré-estabelecidas.

Dos 30 membros que compõem o Conselho Federal, nove serão escolhidos livremente pelo Presidente da República; os restantes 21 representarão os Estados e o Distrito Federal: um para cada unidade da Federação brasileira. Formar-se-á, portanto, uma espécie de Senado educacional, em que, como no Senado político, cada unidade federada, seja qual fôr a respectiva população, tem sempre o mesmo número de representantes. O Estado de São Paulo, por exemplo, com os seus quase 12 milhões de habitantes, elegerá um só conselheiro, tanto quanto o nosso querido vizinho Mato Grosso com os seus 620 mil. No atual Conselho Nacional de Educação, para o qual não foi previsto o regionalismo, o problema da representação dos Estados nunca foi suscitado, nem pareceu que a obediência a êsse critério tivesse qualquer serventia. Cada conselheiro examina, discute e vota todos os casos com igual interêsse, venham do norte, do centro ou do sul do país.

Mas indaguemos ainda:- Por quem são escolhidos os 21 conselheiros do novo cenáculo? A resposta está no parágrafo $10^{\circ}$ do art. $8 .^{\circ}$ do projeto: é pelo Conselho Estadual. Escolherá êste órgão um ou três nomes - enviando-os ao Go- 
vernador a fim de que S. Excia., dentro da pequenina lista, indique o representante do Estado. Pouco trabalho, como se vê, terá o Governador. E mais uma vez pode-se antecipar o resultado. Numa Assembléia classista, como vai ser o Conselho Estadual do projeto, é natural e legítimo que o grupo majoritário eleja em seu próprio seio o representante comum. Demais, visto que, em virtude das condições já expostas, a maioria em todos os Conselhos Estaduais, provirá do magistério particular (a não ser, repetimos, que o Govêrno tome precauções), a conclusão se impõe: devemos esperar que as 21 indicações vindas das unidades federadas reconheçam por origem o mesmo magistério particular. Mais ainda: por circunstância decorrente da simples aritmética eleitoral, tudo leva a crer que predominem os representantes sem diploma, ou sem concurso, ou sem estabilidade.

Pois a êsse Conselho de 30 membros, 21 dos quais, pelo menos, provirão com grande probabilidade do magistério particular, é que o projeto atribui, entre outras coisas, estas, da maior responsabilidade em relação ao ensino brasileiro: autorizar o funcionamento de universidades e aprovar-lhes os estatutos; reconhecer essas mesmas universidades; regular a carreira do magistério; dispor sôbre o currículo obrigatório do curso médio e sôbre os currículos mínimos do curso superior; elaborar anualmente o plano de aplicação dos recursos federais destinados à educação e os quantitativos das bôlsas de estudos ou dos financiamentos; conhecer dos recursos interpostos pelos candidatos ao magistério; avocar a si, quando necessário, as funções dos Conselhos Universitários; etc., etc., etc....

Não é preciso ir além, pois o que acaba de ser dito mostra por si só o absurdo de semelhante organização e faz prever com segurança a falta de idoneidade técnica do novo Conselho Federal, a sua ineficiência e as potencialidades dos defeitos que o processo de sua gênese lhe transmite:- o classismo, o regionalismo e o divisionismo. De uma proeza, entretanto, será êle capaz: a de conduzir ràpidamente ao naufrágio a escola pública do país, a fim de que lhe ocupe o lugar a escola privada - uma escola privada "sui generis", alimentada pelo erário da Nação e só se distinguindo da primeira, quanto aos alunos, por suas discriminações, e, quanto aos professôres, 
pela ausência das provas qualificadoras a que está sujeito o magistério público.

Será o retrocesso, a volta ao passado, a marcha saudosista para o obscurantismo dos séculos anteriores à democracia, em que se impunha a cada um "conhecer o seu lugar" e nêle permanecer a vida inteira. E será sobretudo o aniquilamento da escola leiga, da "escola comum" do continente americano, dessa escola tão maltratada pelos líderes do Brasil e que, mesmo assim, na estreita medida dos seus recursos, vem cooperando bravamente em favor da unidade nacional.

Irá nosso país assistir indiferente a tudo isso? Tenho fé em que não; e em que o Congresso Nacional será o primeiro a impedir essa derrocada de imprevisíveis conseqüências. 